\title{
ethic \\ INDIGENOUS ENVIRONMENTAL INTERESTS AND THEIR CONNECTION TO ANTHROPOGENIC CLIMATE CHANGE
}

\author{
REYES ESPINOZA ${ }^{1}$ \\ (Purdue University/USA)
}

\begin{abstract}
This research reasons through epistemic, journalistic, political, and moral facts and arguments on mitigating or preventing further anthropogenic climate change and preserving natural resources. To slow down anthropogenic climate change global forces, inclusive of governments, NGOs, and collective humanity, should help indigenous peoples to protect their territories and property. Important to the philosophical arguments is understanding the 2015 murder of Berta Cáceres, a Honduran environmental activist, by military members of Honduras at the instruction of the Honduran joint chiefs of staff as well as the likely involvement of an energy company. The conditional that grounds the essay is this: If global forces were to enforce protection of indigenous communities affected by the negative effects of urbanization and globalization, then there would be a mitigating effect on anthropogenic climate change.
\end{abstract}

Keywords: Environmental Ethics; Justice; Climate Change; Honduras; Berta Cáceres.

I will present a modus ponens inference and support it throughout the essay. I call the conditional, its modus ponens inference, and the surrounding premises Argument for Indigenous Environmental Interests. The formalized argument is presented in the next paragraph. The rest of the essay provides explanations and evidence for creating policy and public support for the Argument for Indigenous Environmental Interests as well as justify the moral-political outlook that grounds my concern for Indigenous Environmental Interests (IEIs). A crucial aim of this paper is to theorize about global collective action and praxis, which I see as part of the wider moral-political work we can do as philosophers. To make the planet a place with more justice and moral goodness we need to reason through relevant aspects of anthropogenic climate change, evolutionary psychology, and large-scale societal problems.

Argument for Indigenous Environmental Interests: Premise 1) "Concrete action" is action classified as any combination of political, moral, or personal action. By "entities," I mean any person, group, or procedural institution; Premise 2) Taking something "seriously" is to be moved to a concrete action; Premise 3) Barring climate change skepticism, we ought to desire (A); Premise 4) If (A): we desire protections for sentient ecosystems, including human cities, due to harmful anthropogenic climate change, then (B): we need to take indigenous environmental interests (IEIs) seriously and protect them as a global and local communities; 
Premise 5) Since (B) follows from (A), and we desire (A), we ought to desire (B); Conclusion) Therefore, we - persons, groups, procedural institutions - need to take IEIs seriously, that is, be moved to concrete action that stops harms to them.

The most contentious aspect of the argument is premise 5, the modus ponens inference. After reading the argument, one can reasonably ask if premise 5 true. Does (B) follow from (A)? I will try to motivate the claim that yes-(B) we need to take indigenous environmental interests (IEIs) seriously. I will do this by providing moral reasons for thinking that IEIs in themselves, without regard for climate change, are in danger, but also that they minimally link in the right way - causally connect - to anthropogenic climate change. Global forces of various kinds do harm IEIs and in harming IEIs harm numerous, a relatively large number of, sentient ecosystems — including human cities — on Earth.

I use the case study of the 2015 death of environmental activist Berta Cáceres and her activist and cultural connection to the Lenca people of Honduras to talk about the general harms that occur with IEIs. However, if I fail to convince you that IEIs connect to anthropogenic climate change, I hope you are convinced that IEIs are, indeed, in danger and that they have the moral high ground compared to other groups. There are independent moral reasons and arguments for ascertaining the moral status and, thereby, economic and political protections of IEIs; not as being stewarded by the State, as the USA does with Native Americans-First Nations within its geography, but the State providing respectful, dignified, and effective autonomy and protection. We need to continue to pay attention to the Lenca in Honduras and how their realworld danger from vast global economic and multiple governmental forces occurs, even if their link to anthropogenic climate change and future generations were to weaken.

The following corresponds to important ideas of the paper. What are Indigenous Environmental Interests? Indigenous people near to or owners of significant natural resources for industry; these are 'Indigenous Environmental Interests'. Why care for Indigenous Environmental Interests in terms of anthropogenic climate change? Indigenous people are often near to or own natural resources that are significant for industries, such as the energy sector (oil for gasoline or water for hydroelectric power, etc.) or large plots of land that could be used in agriculture (soy beans, palm oil, coffee, etc.). Historically and as we will see in the section "Berta Cáceres and the systematic killing of indigenous people for significant natural resources," there are instances when investors and company leaders have not compensated indigenous groups fairly and have not protected the environment as they are required by law when cleaning up an area after oil deposits are depleted by industry. Not only this, but there is covert and systematic killing of environmental activists, often of indigenous affiliation, in Latin 
America in direct connection to urbanization or globalization - and by extension anthropogenic climate change. Consequently, how do we start caring about IEIs? To do that, we need to have a proper understanding of two mechanisms that affect planet Earth and human societies: anthropogenic climate change and connections among loyalty, tribal-social-instincts, and values. There are lessons and suggestions to draw and infer from this information to curb damages from anthropogenic climate change, that is, ways to combat negative and foreseeable consequences from anthropogenic climate change.

Now, assume we desire protections for sentient ecosystems, including human cities, due to harmful anthropogenic climate change. At the top of the essay, I called this (A) in the Argument for Indigenous Environmental Interests. We are assuming this; this is my ground. My main aim is to arrive at (B), which is to take indigenous environmental interests (IEIs) seriously and protect them as a global and local communities. My approach in justifying this inference is from epistemic, journalistic, political, and moral disciplines.

\section{Epistemic lessons from Critical Pragmatism to combat negative climate change inducing activities}

The following deals with culture, technology, and world conflicts, especially considering philosophy from early $20^{\text {th }}$ Century to today. Alain Locke, a critical pragmatist, warned against relying on science and technology to close cultural barriers to bring people closer regarding their "factionalisms." Alain Locke claimed that science and technology are "relatively value neutral, and, since they can be fitted in to [sic] such different systems of end values, cannot be relied upon to become deeply influential as unifiers" (Locke 1944/1989b, 76). Locke is essentially saying that science and technology are not enough on their own to unify the world. The world needs to unify through a mechanism other than science. By "unifiers" of humanity, Locke means the end of war between nations and an end of conflict between racial and religious groups. As he says, "The moral imperatives of a new world order are an internationally limited idea of national sovereignty, a non-monopolistic and culturally tolerant concept of race and religious loyalties freed of sectarian bigotry" (Locke 1944/1989c, 152). While these 'moral imperatives of a new world order' may be justified, Locke does not have a perfect answer for how to make these a reality. If there are policies for how to achieve them, keeping in sight that human societies are never static and that what is symbolically meaningful changes (think of the disbanding of the USSR as a nation) — some answers by Locke for achieving moral imperatives for a new world order have a limited window of opportunity. 
However, to search for unifying mechanisms outside of science are proper goals if one believes in amelioration of large-scale conflict of nations, cultures, and religions. Thus, minding evolutionary psychologists such as Richerson and Henrich (see the details of them in the "Praxis and global collective action" section) in their clarifications and research on human evolutiontribal social instincts provide avenues for achieving Locke's moral imperatives for world order in contemporary world society. We can claim without much controversy that science does not control our minds or cultures, even though it may facilitate certain aspects of communication and allows for technological possibilities otherwise not able to be brought into existence. Despite any advance in acquiring economic wealth or acceleration in communication or acquisition of material possessions, Locke contended that such "material issues" could not stop “culture feuds and value intolerances" (Locke 1944/1989b, 76). He continues:

\begin{abstract}
...[science and technology] can quite more easily serve to intensify the conflict as the geographical distance between cultures is shortened and their technological disparities are leveled off. It is, after all, our values and value systems that have divided us apart from and in many cases over and above our material issues of rivalry and conflict. If we are ever to have less conflict and more unity, it must come about in considerable part from some deep change in our value attitudes and our cultural allegiances. The increasing proximity of cultures in the modern world makes all the more necessary some corrective adjustment of their "psychological distance." (Locke 1944/1989b, 76-77; emphasis mine)
\end{abstract}

As a quick aside, this passage is not to be interpreted as "anti-science." It is to be properly interpreted as identifying a limitation of science in human civilization and global society to work toward solutions that have this limitation in the background. The upshot is that since cultures and value attitudes are what divide people, what creates "psychological distance" when they are in serious opposition, scientific and technological enterprises can do little on their own to bring us together, and in some cases may intensify conflicts. Science and technology may drive us apart as tools of war and destruction of communities or by protecting immorally entrenched corporate and economic interests.

\title{
Critiquing ethical theories for being insufficiently action guiding
}

Stephen M. Gardiner (2011) claims that in the "theoretical storm" climate change involves the intersection of many problems. The theoretical storm is comprised of problems with the "best" candidate political and moral theories for reasoning about the planetary environment (Gardiner 2011, 41). Conventional approaches to public policy are not well equipped to handle the following problems associated with the theoretical storm: 1) Uncertainty 
of climate models; 2) the very long-term; and 3) the creation of different preferences and persons (Gardiner 2011, 213). There are many dimensions for possible alterations to the planetary climate, and we do not know all the negative or positive consequences that could come about (Gardiner 2011, 189).

Gardiner constructs four salient change scenarios in terms of the planetary climate that are important for the security concerns of humanity and for the well-being of our and future generations: Scenario 1, Soft Landing: creeping change with significant but highly malleable, negative impacts; Scenario 2, Rough Landing: Substantial change with major, and moderately malleable, negative impacts; Scenario 3, Hard Landing: Dramatic change with severe, and poorly malleable, negative impacts; Scenario 4, Crash Landing: Spectacular change with catastrophic negative impacts with no malleability $(2011,223-224)$.

For Gardiner, conventional institutions and theories can likely handle the first two change scenarios (Soft and Rough Landings), but they are not likely to handle the latter two (Hard and Crash Landings). Applying the framework of Jane Gordon and Lewis Gordon (2009/2016), climate change runs on a continuum of disaster and catastrophe (8-9). There is the scientific facts and predictions that models and climate scientists can tell us about, then there is the social implications and collective action we can enact (or not) to mitigate or prevent disasters that become catastrophes that become disasters that become catastrophes, ad infinitum. We may learn to heed the warnings of destruction and choose, through collective strategy, to mitigate or prevent the negative effects from anthropogenic climate change. Gardiner's salient change scenarios are important to keep in mind to refine the theoretical debate on the continuum of disaster that climate change signifies. We can use the scenarios to help us decide how to mitigate or prevent further negative, disastrous, and catastrophic effects from anthropogenic climate change. Summarizing Gardiner's worries, the latter two scenarios, Hard and Crash Landings are the most worrisome in relation to conventional institutions and theories $(2011,224)$. Gardiner realized that values are at the heart of the climate change debate. Hence, what system of values you adopt and prefer is important in mitigating and preventing negative consequences of climate change. Using Gardiner's framework, when conventional theories and institutions are bad at handling certain scenarios, as they are when it comes to the Hard Landing and Crash Landing, they should be criticized for it. However, they should not only be criticized, but alternative solutions should be found.

\section{Suggestions for anthropogenic climate change mitigation or prevention: Protect IEIs}


Haidt (2011) provides moral psychologists with the moral foundation of loyalty/betrayal. This is one moral component that can be used to the advantage of those wishing to address climate change. Based on the preceding considerations by Locke, it is necessary to find "corrective adjustments" to the "psychological distance" between societies and cultures, especially since scientific findings and new technologies keep closing the geographical gap between them, which has the potential to create conflict if left unchecked $(1944 / 1989 b, 77)$.

Here is one set of suggestions helpful to those wishing to stop or slow down anthropogenic climate change: Lessons from Leonard Harris's work on philosophy of race can help protect IEIs. "The forces that unite humanity-such as common dominators of class interest, inclinations to pursue status, disdain for injustice to members of one's perceived community — can be marshalled to aid the destruction of sinister, unintentional, and structural racial formations of oppression" (Harris 1999, 449). Not only can they be marshalled to destroy oppressive racial formations, but they also can be marshalled to destroy climate change disasters. Harris's historical research and philosophical analyses on Alain Locke shows in this set of recommendations. One can recognize the respect and working-out of problematics from Alain Locke's theories.

One of the most entrenched and hardest of topics to discuss in the mind of those in the USA is race. The topic of race shares this with the topic of climate change: even though it is all-encompassing and affects our social surroundings, it is hard to pick out its boundaries, since it is ubiquitous. Thus, if Harris's suggestions are good for dismantling racial oppression (and I believe they are), they are on the right track for us regarding climate change proposals to change culture when it comes to behaviors that would lead to climate protection. For changing culture around climate change, I will only expound on the last of the set Harris presents: "disdain for injustice to members of one's perceived community."

If indigenous groups, such as the Lenca, are part of our perceived community, we will be outraged at the treatment they have received and receive at the actions of national militaries and some energy corporations. This would be because we have a "disdain for injustice to members" of our community.

If indigenous groups are a part of our perceived community, we will disdain injustices they experience-injustice that hurts even more when we know that it is not only their human dignity that is being trampled on, but also the soil that feeds them (and millions of others). Still more outrageous and hurtful to us should be the killing of farmer activists in Central America in the process of disputes over land acquisition and reallocation from one indigenous group to nations or corporate entities. These injustices when voiced should outrage us and move us to 
action, to praxis. Granted, not every injustice can move us to action against that specific injustice since we have complicated lives filled with countless activities. Still, if no injustice moves us to action, we are not fulfilling our political, moral, and civic duties as inheritors of nations, of the world, or as moral agents.

\section{Berta Cáceres and the systematic killing of indigenous people for significant natural resources}

I will explain the situation with Berta Cáceres and the systematic killing of indigenous people for significant natural resources by State powers, since it is their realities that my arguments seek to remedy. By "State powers" I mean chains of administration from governmental entities, such as governors, military officials, or city councils. Berta Cáceres, cofounder of National Council of Popular and Indigenous Organizations of Honduras (Consejo Cívico de Organizaciones Populares e Indígenas de Honduras, COPINH) and organizer for the Lenca indigenous group (BBC Mundo, 2016, March 3), is a recently murdered environmental activist from Honduras, killed March 2 ${ }^{\text {nd }}, 2016$ (El País, 2017, March 3; La Prensa Gráfica, 2016, May 10). Berta won the 2015 Goldman Environmental Prize, "the world's leading environmental award" as a "recognition" for her successful efforts in effectively battling "to stop construction" (The Guardian, 2015, April 19) at the "Agua Zarca [project]...one of four dams planned in the Gualcarque river basin" (The Guardian, 2016, March 4).

Berta was killed by military members from Honduras at the command of then active military officials of the country, according to credible testimony from First Sergeant Rodrigo Cruz (a pseudonym), whose identity was confirmed by "academics, community leaders, and activists" (The Guardian, 2016, June 21). Berta’s daughter, Olivia Zúñiga, in an interview on Nicaraguan television, accused the Honduran federal government ["el Estado"], the military ["Fuerzas Armadas"], and Desarollos Energéticos S.A. (DESA) of being complicit in orchestrating the murder ["autores intelectuales" del asesinato] of her mother (La Prensa Gráfica, 2016, May 10). One suspect arrested for the murder connected to DESA was employee Sergio Rodríguez Orellana, manager of social and environmental issues for DESA, who said he was "surprised" by his detainment (The New York Times, 2016, May 2).

Berta's death is not an isolated incident. Chris Moye from Global Witness told BBC Mundo that of the 111 murders from 2002-2014 in Honduras of environmental activists 80 of them were in the Bajo Aguán region from 2011-2014 (March 3, 2016). Chris Moye further claims that Berta's death is representative of "systematic persecution" of Honduran 
environmentalists (BBC Mundo, March 3, 2016). Relatedly, “The Bajo Aguán region-where the Xatruch taskforce is based [Rodrigo Cruz's former military unit] — has been the setting for a string of violent land disputes between powerful palm oil magnates and local farmers. More than 100 people, mainly peasant activists, have been killed, many at the hands of state or private security forces" (The Guardian, June 21, 2016). Our loyalties should be with Berta and her memory, supporting COPINH and environmental groups like it, that is, IEIs. We must side with Berta's memory and groups like COPINH by doing what we can, including monetary support and political activism, to support them.

\section{The dual moral case to protect Indigenous Environmental Interests}

There are two moral arguments for IEIs that I want to now formalize. So far, I have epistemically, journalistically, and politically supported, especially founded on the effects of anthropogenic climate change, the Argument for Indigenous Environmental Interests. I have provided philosophically robust reasons - from various philosophical traditions - for inferring from the antecedent (If (A): we desire protections for sentient ecosystems, including human cities, due to harmful anthropogenic climate change), the consequent (then (B): we need to take indigenous environmental interests (IEIs) seriously and protect them as a global and local communities). The first moral argument I want to formalize is based on survival concerning planet Earth and its inhabitants, alongside the threat of anthropogenic climate change. The second is being against racism while protecting IEIs, from a basic commitment to universal human liberation.

Preservation of planet Earth should be the concern of any of its inhabitants. Existential threats to the planet are bad long-term business, bad morals, bad for any species that cannot live outside the Earth's atmosphere. If anthropogenic climate change reaches some thresholds for rising global temperatures, the impacts on planetary ecosystems may not only be irreversible, but existential threats to an unpredictable, but large, number of species and their membership, including human beings. Protecting IEIs can mitigate or prevent aspects of anthropogenic climate change. Since some IEIs are, in some cases, forests and these aid as carbon-sinks, their protection is a mitigating factor, at least against $\mathrm{C} 02$. A different study would need to confirm the extent of this conclusion, as my evidence and empirical reasoning are limited. I take the existential threat argument concerning IEIs to be not only a moral issue, but also a practical solution, that is, a theoretical space where moral rightness and global collective action meet. While uncertain due to lack of data how much IEIs mitigate or prevent negative consequences 
of anthropogenic climate change, we can reasonably state that stopping parts of an existential threat are a good, and this is precisely what protecting and preserving IEIs does.

The second moral argument is being against racism while protecting IEIs, from a basic commitment to universal human liberation. This morally justifies one reason to protect IEIs. What is universal human liberation? "Universal human liberation is tied, for Harris, to open communities. Thus, he defines "American philosophy" in ways that include ethno-philosophies (philosophies that are created by a people and defined by their values and practices), but focuses on philosophies created by individuals who develop unique arguments and methods" (Harris, Pratt, and Waters 2002, 1). We should understand Berta's actions as developing "unique arguments and methods." Her recognition with the 2015 Goldman Environmental Prize by the international community is an instance of her arguments and methods being widely recognized and endorsed by a prestigious philanthropic foundation that consults with environmental experts and organizations (Goldman Environmental Foundation 2019). Furthermore, "Everyone arrived from somewhere else; no human populations were ever owners, users, or agents commuting with natures in a static location and in isolation from others from the beginning of time... Every native or indigenous population is itself a consequence of earlier population growth, migration, or invasion" (Harris 2002, 5). This leads us to infer that no group or individual has a moral right to the entire Earth, since we are temporally bound to special regions of the planet. Racism in its multiple insidious forms is often tied to reallocation or basic distribution of land and property. This is one covert mechanism by which IEIs are being disrespected and reallocated (sometimes to the point of stolen) through the justification of the utilitarian calculus of urban development from stronger national governments with militaries. Lewis R. Gordon (1995/1999) states, "One fights against racism to liberate human beings" (354). Where my force infringes on my fellow human beings, I must stop my action. I will then evaluate and find a way to not infringe on them.

\section{Praxis and global collective action: Loyalty, tribal social instincts, and values in relation to anthropogenic climate change}

One recent important book in moral psychology is Jonathan Haidt's The Righteous Mind: Why Good People Are Divided by Politics and Religion published in 2011. Haidt claims to provide a highly plausible account of how human morality differs from other species and how it has helped us achieve large-scale cooperation. Haidt says, "...morality is the extraordinary human capacity that made civilization possible" (2011, Introduction). Moreover, 
it includes loyalty in its explanation of large-scale cooperation (chapter 7, section The Moral Foundations of Politics). Haidt agrees with neuroscientist Gary Marcus's analogy that the brain is a "first draft" of a book that nature provides. The brain, so the analogy goes, has language, morality, sexuality, etc. written on it, and one's upbringing and social circumstances shape it further in time (chapter 7, section A Note on Innateness). Haidt argues that "Secular West" moralities have a propensity to speak of and account for "harm and suffering" and "fairness and injustice," while largely ignoring four moral "taste receptors" (Haidt, 2011, Introduction, section What Lies Ahead). Those four moral values or "receptors" are "liberty, loyalty, authority, and sanctity" (Haidt, 2011, Introduction, section What Lies Ahead). In Haidt's "Moral Foundations Theory" foundation number three is loyalty/betrayal. Haidt states, "The Loyalty/betrayal foundation is just a part of our innate preparation for meeting the adaptive challenge of forming cohesive coalitions. The original trigger for the loyalty foundation is anything that tells you who is a team player and who is a traitor, particularly when your team is fighting with other teams" (2011, chapter 7, section The Loyalty/Betrayal Foundation). Haidt has given moral psychology much to build on and ponder going forward regarding the foundations of morality and, for my purposes, has given an excellent introduction to understanding loyalty in general through the Loyalty foundation-again, composed of loyalty and betrayal.

An exploration and explanation of loyalty in the debate on the effects of global climate change by humanity is of the utmost importance if we want to help solve the theoretical problems with political and moral institutions Gardiner analyzes. While Gardiner does an excellent job in examining the convergence of the global, intergenerational, and theoretical aspects of this debate, his analysis of why we 'pass the buck' is incomplete without accounting for why people choose some commitments rather than others. 'Passing the buck' in our case refers to one generation of humans having knowledge of climate change's dire effects, but hoping, expecting, or not caring that a future generation finds ways to survive possible catastrophic effects. The alternative is the current generations taking on the challenge.

Humans are typically loyal to individual people, rather than to abstract categories of people as aggregates. Gardiner states, “...the affective mechanism [as opposed to the "analytical" mechanism] is likely to result in a particular problems' being marginalized by other-perhaps objectively less important concerns...” (2011, 194). The analytical and affective mechanisms "acquire information in different ways: the affective tends to rely on personal experience, whereas the analytical favors statistical descriptions..." $(2011,193)$. Thus, I conjecture, it is (to varying degrees) easier to have loyalty to individual people and smaller 
groups than to bigger groups and the species. Consequently, an example that does not readily activate our cognitive mechanism for loyalty is future generations, especially when they are not one's children or one has no personal connection. Future generations are impersonal "categories" instead of, as Miguel de Unamuno in Tragic Sense of Life phrased, "flesh and bone" persons who suffer and die, especially die $(1921 / 1954,1)$.

Part of the project of this paper tries to elucidate a sense of justice for future generations. Providing justice to indigenous populations around the world that are adversely affected by anthropogenic climate change is one way to do this. Anthropogenic climate change, to make clear, largely occurs because of negative aspects of globalization and urbanization. So long as urbanization keeps encroaching on natural ecosystems by destroying species of animals and plants-sometimes key species such as apex predators-human civilization will become increasingly reliant on technologies that create environments, rather than work in them. This poses serious issues for logistics and overall feasibility.

The evolution of humanity is a topic often hard to breach. It is much easier to understand how other animals evolved, but, despite the complexities, humans have a long history of evolution. "The evolution of humans from primate ancestors involved the evolution of sympathy, loyalty, and pride in one's contribution to the group. These qualities originally supported simple tribes in which food was shared, territory defended, and rules enforced without any top-down leadership" (Richerson \& Henrich 2012, 57). Sympathy, loyalty, and pride are three emotions or functional values that form a substantive part of humanity's "tribal social instincts." Undergirding these instincts, which still accompany human societies, is "geneculture coevolution" (Richerson \& Henrich 2012, 38). A comprehensive and concise description of this process is the following:

The cultural and genetic elements of our social psychology interacted over the long run of human evolution. To judge from the stone tools humans left behind...human cultural sophistication probably evolved in several waves after about 2.6 million years ago....Molecular evidence suggests that humans have undergone a burst of genetic evolution in the wake of the origins of agriculture and some controversial arguments hold that psychological traits as well as those related to disease and diet responded in a major way to the development of food production and the larger, more sophisticated societies it made possible. (Richerson \& Henrich 2012, 58)

Thus, tribal social instincts are in place in humans today because of early humans' circumstances and their ongoing interaction with other humans and locales throughout history. In line with the evidence, "enormous collective action enterprises" were made possible by "our ability to cooperate and trust conditionally" (Richerson \& Henrich 2012, 58). Interestingly, for 
Daniel Dennett, "Our wills are free, in the morally relevant sense, because our ancestors' superior capacities to take responsibility and commit to courses of action gave them comparable advantages over competitors" (Zawidzki 2007, 126). Cooperation and trusting conditionally are consequences from the evolution of sympathy, loyalty, and pride.

Based on Richerson and Henrich, tribal social instincts must be engaged in intergroup cooperation to facilitate large-scale cooperation, even in contemporary societies. My analyses of Leonard Harris's philosophical investigations on Alain Locke on the advantages and disadvantages of science and culture in the preceding section "Suggestions for anthropogenic climate change mitigation or prevention" cohere with this part of Richerson and Henrich's investigations on tribal social instincts, without him explicitly having them in mind.

In conjunction with contemporary ongoing cultural evolution, human organizations today operate on principles shaped by tribal social instincts from early humans. Organizations that have too many employees that act selfishly as opposed to having a wider concern for the continuation of the organization tend to be worse off than those that have 'good norms'; good norms in this context are "social norms that effectively harness aspects of our evolved psychology in ways that led to success in inter-group competition" (Richerson \& Henrich 2012, 57). Overtime, cultural evolution has favored these kinds of groups because they engage our evolved psychology, which tends to benefit the group.

Having the capacity to be loyal does not of itself dictate who you should be loyal to. On this point, Gardiner says, “The perfect storm constitutes a non-neutral evaluative setting, and this poses special challenges for ethical action...we must pay attention to the ways important values are articulated, since the likelihood of their perversion is high" (2011, xi). Similarly, Alain Locke endorsed a reconceptualization of the concept of loyalty and its application.

...the Roycean principle of "loyalty to loyalty," which though idealistic in origin and defense, was a radical break with the tradition of absolutism. It called for a revolution in the practice [sic] of partisanship in the very interests of the values professed. In its larger outlines and implications it proclaimed a relativism of values and a principle of reciprocity [that dictates no culture stays static and that cultures take from many sources to create their practices]. (Locke 1935/1989a, 49)

An obvious difference between Alain Locke and Gardiner is that Gardiner is not a fullblown relativist about values. At the same time, Locke's relativism about values may be more palatable to the reader than other formulations of relativism. Take Harris's summary of value ultimates or imperatives in his "Introduction" to Locke's A Functional View of Value Ultimates, "Value ultimates or imperatives are really "system imperatives rather than intrinsic absolutes." 
Values are functional transpositional systems" (1989, 79). Furthermore, values, rules, or imperatives, that is, the "regulative normative rules we adopt" (Harris 1989, 80) are not only important to know for those of use working in moral philosophy and normative issues generally, but how we adopt and accept them are just as important. There may be normative rules that seem to be morally correct in theory, but if they are completely counter to how we adopt or accept them cognitively, they would violate the following ethical reality: Ethics cannot command or recommend for us, in this case joint action, to do the impossible. There are cases where the lines between the impossible and the improbable are not clear, but in a great deal of cases the lines are ethically and logically clear.

In sum, values play an important role for both Locke and Gardiner when it comes to collective action on a world-scale and they both believe that some values are not conducive to positive large-scale human cooperation.

\section{Conclusion}

Can we care about the ecosphere, the planetary environment, in the abstract? No, most of us cannot. I have argued that engaging our sense of loyalty is key to protecting and securing long-term human interests and the long-term survival of environments such as forests, rivers, oceans, and animals that reside therein. One could use explanations for tribal social instincts and the suggestions for engaging the human sentiment of loyalty to help either corporations trying to extract key natural resources from indigenous lands or to help indigenous groups supporting environmental protections. I argued for supporting the Argument for Indigenous Environmental Interests. The main argument is premises three through six in the introduction to this essay. Throughout the essay, I offered several supporting epistemic, journalistic, political, and moral reasons for protecting planet Earth and humanity by mitigating or preventing anthropogenic climate change. 


\section{Note}

$1 \mathrm{PhD}$ in Philosophy from Purdue University (2019), Indiana, United States of America. E-mail: reyes.espinoza.zapata@gmail.com 


\section{References}

DPA. (2016, May 10). Hija de Berta Cáceres culpa a empresa desa, a estado y militares hondureños de asesinato. La Prensa Gráfica. Retrieved from http://www.laprensagrafica.com/2016/05/10/hija-de-berta-caceres-culpa-a-empresa-desa-aestado-y-militares-hondureos-de-asesinato

Garcia, Jacobo. (2017, March 3). La muerte inútil de la ecologista hondureña berta cáceres. El País. Retrieved from https://elpais.com/internacional/2017/03/02/america/1488478328_257627.html

Gardiner, Stephen. M. (2011). The perfect storm: The ethical tragedy of climate change [Kindle Cloud Reader version]. Available from Amazon.com

Goldman Environmental Foundation. (2019). https://www.goldmanprize.org/

Gordon, Jane A. \& Gordon, Lewis R. (2016). Of Divine Warning: Reading Disaster in the Modern Age. New York: Routledge. (Originally published 2009)

Gordon, Lewis R. Antiblack Racism and Ontology. In L. Harris (Ed.), Racism (pp. 347-355). New York: Humanity Books.

Haidt, Jonathan. (2011). The righteous mind: Why good people are divided by politics and religion [Kindle Cloud Reader version]. Available from Amazon.com.

Harris, Leonard. (1999). What, then, is Racism? In L. Harris (Ed.), Racism (pp. 437-450). New York: Humanity Books.

Harris, Leonard (2002). Prolegomenon to a Tradition: What is American Philosophy? In L. Harris, S.L. Pratt, and A.S. Waters (Eds.), American Philosophies: An Anthology (pp. 5-6). Malden, MA: Blackwell Publishers.

Harris, Leonard, Pratt, Scott L., \& Anne S. Waters. (2002). Introduction. In L. Harris, S.L. Pratt, and A.S. Waters (Eds.), American Philosophies: An Anthology (pp. 1-4). Malden, MA: Blackwell Publishers.

Lakhani, Nina. (2016, June 21). Berta cáceres's name was on honduran military hitlist, says former soldier. The Guardian. Retrieved from https://www.theguardian.com/world/2016/jun/21/berta-caceres-name-honduran-militaryhitlist-former-soldier

Locke, Alain. (1989a). Values and imperatives. In L. Harris (Ed.), The philosophy of alain locke: Harlem renaissance and beyond (pp. 34-50). Philadelphia: Temple University Press. (Original work published 1935)

- (1989b). Cultural relativism and ideological peace. In L. Harris (Ed.), The philosophy of alain locke: Harlem renaissance and beyond (pp. 69-78). Philadelphia: Temple University Press. (Original work published 1944) 
- (1989c). Moral Imperatives for World Order. In L. Harris (Ed.), The philosophy of alain locke: Harlem renaissance and beyond (pp. 151-152). Philadelphia: Temple University Press. (Original work published 1944)

Malkin, Elisabeth. (2016, May 2). Honduras arrests 4 men in killing of berta cáceres, indigenous activist. The New York Times. Retrieved from

https://www.nytimes.com/2016/05/03/world/americas/honduras-arrests-4-men-in-killing-ofberta-caceres.html?mcubz $=3$

Martins, Alejandra. (2016, March 3). Honduras: matan a berta cáceres, la activista que le torció la mano al banco mundial y a china. BBC Mundo. Retrieved from http://www.bbc.com/mundo/noticias/2015/04/150423 honduras_berta_caceres_am

Richerson, Peter \& Henrich, Joe. (2012). Tribal social instincts and the cultural evolution of institutions to solve collective action problems. Cliodynamics, 3(1), 38-80.

Unamuno, Miguel de (1954). Tragic Sense of Life. (J. E. Crawford Flitch, Trans.). Printed and bounded in United States of America: Dover Publications. (Originally published 1913 in Spanish. Originally published 1921 in English)

Watts, Jonathan. (2016, March 4). Berta cáceres, honduran human rights environment activist, murdered. The Guardian. Retrieved from https://www.theguardian.com/world/2016/mar/03/honduras-berta-caceres-murderenivronment-activist-human-rights

- (2015, April 19). Honduran indigenous rights campaigner wins Goldman prize. The Guardian. Retrieved from https://www.theguardian.com/world/2015/apr/20/honduranindigenous-rights-campaigner-wins-goldman-prize

Zawidzki, Tadeusz. (2007). Dennett. Oxford: Oneworld Publications. 